\section{THU0276 HIGH HYDROXYCHLOROQUINE EXPOSURE IS ASSOCIATED WITH ABNORMAL STRAIN IMAGING IN LUPUS PATIENTS WITH END-STAGE RENAL DISEASE}

A. Londono Jimenez ${ }^{* 1}$, M. H. Mustehsan ${ }^{1}$, J. Law ${ }^{1}$, A. Valle ${ }^{1}$, M. Salgado Guerrero $^{1}$, C. Taub ${ }^{1}$, A. R. Broder ${ }^{1} .{ }^{1}$ Montefiore Medical Center/Albert Einstein College of Medicine, New York, United States of America

Background: Hydroxychloroquine (HCQ) cardiotoxicity remains an underrecognized condition. Diagnosis ultimately relies on invasive endomyocardial biopsy $(E M B)$ and non-invasive screening methods are warranted. Strain imaging is a novel tool to detect early subclinical left ventricular (LV) dysfunction and may have a role in screening for HCQ cardiotoxicity (1). Strain measures systolic deformation indices that when decreased can predict cardiovascular outcomes more accurately than LV ejection fraction (2).

Objectives: We assessed whether high $\mathrm{HCQ}$ cardiotoxicity risk is associated with a specific strain pattern in a group of patients with SLE and end-stage renal disease (ESRD)

Methods: This was a retrospective study in a tertiary care center in New York on a group of patients with an established diagnosis of SLE, ESRD and cardiomyopathy on the index echocardiogram followed between years 2003 and 2019. The patients were stratified into two groups: high risk HCQ toxicity group was defined as either cumulative $\mathrm{HCQ}$ dose $\geq 1000 \mathrm{~g}$ and/or an endomyocardial biopsy confirming HCQ toxicity. Low/moderate risk group was defined as a cumulative dose of $\mathrm{HCQ}<1000 \mathrm{~g}$. Clinical, demographic, electrocardiographic and echocardiographic strain parameters were compared between the groups.

Results: A total of 16 patients were included. Two patients had EMB consistent with $\mathrm{HCQ}$ induced toxicity and 3 patients had cumulative $\mathrm{HCQ}$ doses $\geq 1000 \mathrm{~g}$. There were no significant differences in the baseline demographic characteristics between the two groups. Compared to patients with low/moderate risk, patients in the high risk group had a lower heart rate at the time of the echocardiogram ( 69 vs 87 beats per minute, $p=0.08$ ) and a higher frequency of LV hypertrophy $(40 \%$ vs $9.1 \%, p=0.2)$. Strain analysis showed that both groups had compromised LV global longitudinal strain (GLS) and global cross-sectional strain (GCS). However, compared to the low/moderate risk group, the high risk group had a weaker LV GLS $(-12.3 \%$ vs $-14.9 \%, p=0.27)$.

\section{Characteristics overall and stratified by HCQ risk group}

\begin{tabular}{|c|c|c|c|c|c|}
\hline & Characteristic & Overall $(n=16)$ & $\begin{array}{c}\text { Low/Moderate } \\
\text { HCQ } \\
\text { Risk(n=11) }\end{array}$ & $\begin{array}{l}\text { High HCQ Risk } \\
\text { and/or Positive } \\
\text { EMB }(n=5)\end{array}$ & $\begin{array}{c}P \\
\text { value }\end{array}$ \\
\hline \multirow[t]{2}{*}{ Demographics } & Age, years & $47.5(36.5,60.7)$ & $\begin{array}{c}50.0 \\
(33.9,60.5)\end{array}$ & $42.5(42.7,61.0)$ & 0.95 \\
\hline & Female, n(\%) & $14(87.5)$ & $9(90)$ & 5 (83.3) & 0.99 \\
\hline \multirow[t]{7}{*}{ Clinical Features } & $\begin{array}{l}\text { SLE duration, } \\
\text { years }\end{array}$ & $7.4(4.3,17.5)$ & $5.5(3.5,13.2)$ & $15.6(11.6,19.3)$ & 0.15 \\
\hline & $\begin{array}{l}\mathrm{HCQ} \text { cumulative } \\
\text { dose, } \mathrm{g}\end{array}$ & $\begin{array}{c}422.8 \\
(224.2,422.8)\end{array}$ & $\begin{array}{c}285.4 \\
(110.8,523.6)\end{array}$ & $\begin{array}{c}1140 \\
(1006,1625.4)\end{array}$ & 0.005 \\
\hline & $\begin{array}{l}\mathrm{HCQ} \text { therapy } \\
\text { duration, years }\end{array}$ & $3.4(2.5,8.9)$ & $3.2(1.5,5.1)$ & $7.8(6.8,11.6)$ & 0.06 \\
\hline & $\begin{array}{l}\mathrm{HCQ} \text { daily dose, } \\
\mathrm{mg} / \mathrm{d}\end{array}$ & $\begin{array}{c}226 \\
(200,394.9)\end{array}$ & $\begin{array}{c}200 \\
(179.4,253.7)\end{array}$ & $400(389.8,400)$ & 0.007 \\
\hline & $\begin{array}{l}\text { Hypertension, } \\
\mathrm{n}(\%)\end{array}$ & $14(87.5)$ & $10(90.9)$ & $4(80.0)$ & 0.99 \\
\hline & Diabetes, n (\%) & $3(18.8)$ & $2(18.8)$ & $1(20.0)$ & 0.99 \\
\hline & CAD, n (\%) & $3(18.8)$ & $2(18.8)$ & $1(20)$ & 0.99 \\
\hline \multirow[t]{5}{*}{ Echocardiogram } & EF, \% & $55(42.5,60)$ & $55(40,60)$ & $55(55,70)$ & 0.45 \\
\hline & LA size, $\mathrm{cm}$ & $3.8(3.4,4.3)$ & $3.8(3.4,4.2)$ & $4.3(3.4,4.9)$ & 0.30 \\
\hline & LVEDD, cm & $4.9(4.4,5.5)$ & $4.8(4.2,5.5)$ & $5.0(4.9,5.4)$ & 0.43 \\
\hline & E/E' & $12.3(8.8,16.3)$ & $12(8.8,14.9)$ & $16.9(4.9,21.8)$ & 0.43 \\
\hline & $\begin{array}{c}\text { Moderate-severe } \\
\text { LV hypertrophy, } \\
\mathrm{n}(\%)\end{array}$ & $3(18.7)$ & $1(9.1)$ & $2(40.0)$ & 0.20 \\
\hline \multirow[t]{4}{*}{$\begin{array}{l}\text { Strain } \\
\text { echocardiography }\end{array}$} & GLS, \% & $\begin{array}{c}-13.9 \\
(-16.7,-12.3)\end{array}$ & $\begin{array}{c}-14.9 \\
(-16.7,-12.9)\end{array}$ & $-12.3(-15.4,-12.2)$ & 0.27 \\
\hline & Base/Apex Ratio & $0.8(0.7,0.9)$ & $\begin{array}{c}0.76 \\
(0.68,0.86)\end{array}$ & $0.76(0.66,0.83)$ & 0.95 \\
\hline & GCS, \% & $-20.2(-21.7,-17)$ & $\begin{array}{c}-19.7 \\
(-20.5,18.0)\end{array}$ & $-21.7(-23.9,-20.9)$ & 0.16 \\
\hline & RV GLS, \% & $\begin{array}{c}-20.19 \\
(-22.1,-17.5)\end{array}$ & $\begin{array}{c}-20.2 \\
(-22.3,-17.1)\end{array}$ & $-19.8(-22.1,-17.5)$ & 0.99 \\
\hline
\end{tabular}

Conclusion: We report an association of higher $\mathrm{HCQ}$ cardiotoxicity risk and impaired strain in a set of SLE ESRD patients. Standard echo measures did not differentiate between high and low/moderate risk patients. Although the findings did not reach statistical significance, given the small sample size, results are still suggestive of a possible utility of strain echocardiography for detection of early HCQ toxicity.

\section{References:}

[1] Buss SJ, et al. J Rheumatol. 2010;37(1):79-86

[2] Kalam K, et al. Heart. 2014;100(21):1673-80

Disclosure of Interests: None declared

DOI: 10.1136/annrheumdis-2020-eular.5487

\section{THU0277 THE EXPRESSION OF IFNA, INFB AND INFr AND SERUM LEVELS OF THOSE CYTOKINES IN SJÖGREN'S SYNDROME PATIENTS}

M. Maślińska ${ }^{1}$, A. Paradowska-Gorycka ${ }^{2}$, A. Wajda ${ }^{2}$, K. Kostyra-Grabczak ${ }^{1}$,

B. Kwiatkowska ${ }^{1}{ }^{1}$ National Institute of Geriatrics, Rheumatology and

Rehabilitation, Early Arthritis Clinic, Warsaw, Poland; ${ }^{2}$ National Institute of

Geriatrics, Rheumatology and Rehabilitation, Molecular Biology Department, Warsaw, Poland

Background: In the pathogensis of autoimmune mediated diseases, such as Sjögren's syndrome (SS), interferons (IFN) and IFN pathway activation play a vital role.

Objectives: We planned to assess IFNa, INF $\beta$ and INFY expression and IFNs serum levels in SS patients and correlation of these parameters with: autoantibodies specific for SS, serum concentration of $\mathrm{C} 3, \mathrm{C} 4$ component of complement (C3, C4), rheumatoid factor (RF), gammaglobulins, focus score (FS) and eye dryness symptoms.

Methods: Whole blood RNA was isolated from 77 SS patients [F91\%vsM9\%]; mean age 49,69 15.36; SS diagnosis according to EULAR/ACR 2016 criteria. The analysis of INFa, $-\beta$ and $-\gamma$ expression levels was based on validated TaqMan probes by $\Delta C T$ methods. Serum concentrations of rheumatoid factor (RF), C3- and C4 complement components ( $\mathrm{mg} / \mathrm{dL}$ ) and gammaglobulins $(\mathrm{g} /$ $\mathrm{dL}$ ), were assessed. Anti-Ro/SSA and/or anti-La/SSB autoantibodies were assessed by semiquantitative immunoblotting evaluation. The eye dryness and keratoconjunctivitis sicca were confirmed with Schirmer's test (score of less than $5 \mathrm{~mm} / 5^{\prime}$ ) and the ocular staining score (OSS) using lissamine green and fluorescein staining. The biopsy of minor salivary gland was performed with the histopathological evaluation of FS. The study was approved by the Bioethics Committee. Differences between groups of patients were determined using non-parametric Mann-Whitney $U$ test or Kruskall-Wallis test with Dunn's post hoc. Correlations were determined using nonparametric Spearman test. The level of statistical significance was set at $p$ $<0.05$

Results: IFN $\beta$ had the highest expression levels among IFNs and IFN $\beta$ serum concentrations were higher than those of IFNa and $-\gamma$. In cases with high IFN $\beta$ serum concentration lower IFN $\beta$ expression was observed. There was a highly significant correlation between IFNa and IFN $\beta$ expression $(r=0.6 ; p=0.001)$. IFN $\beta$ expression $(p=0.059)$ was higher in the group of younger ( $<45$ y.o.) patients ( $n=23 ; 29.9 \%$ ) as compared to the group of older individuals (at least 45 y.o.). In patients with SS-A / Ro antibodies with strong antigen binding affinity (3) IFN $\beta$ expression and IFN $\beta$ serum levels were highest of all IFNs. The presence of anti La/SS-B antibodies was associated with the increased IFN $\beta$ expression while not with the increased IFN $\beta$ serum concentration. In terms of IFNa expression and protein level, $\mathrm{RF}(+)$ patients had average higher values compared to RF(-) patients. The average mRNA level of IFNa was about 3 times lower in patients with low $\mathrm{C} 3$ serum concentration compared to patients with normal C3 serum concentration values. IFN $\beta$ mRNA level was 2.5 times lower in patients with low Schirmer's test $\left(<5 \mathrm{~mm} / 5^{\prime}\right)$ in comparison to patients with Schirmer's test $>5 \mathrm{~mm} / 5^{\prime}$; Schirmer's test $<5 \mathrm{~mm} / 5$ ' was associated with higher IFN $\beta$ serum concentration.

Conclusion: Type I IFN signature predominates in the peripheral blood of studied patients. Presented results confirmed the pivotal role of type I IFN in the disease process. The serum concentration of IFN $\beta$ and the expression of IFN $\beta$ were the highest values of those parameters for cytokines assessed in this study. A positive correlation between IFNa and IFN $\beta$ mRNA levels has been observed.

Disclosure of Interests: None declared

DOI: 10.1136/annrheumdis-2020-eular.1194

\section{THU0278 NAILFOLD CAPILLAROSCOPY IN SJÖGREN'S SYNDROME: A SYSTEMATIC LITERATURE REVIEW AND STANDARDISED INTERPRETATION}

K. Melsens ${ }^{1}$, M. C. Leone ${ }^{1,2}$, S. Paolino ${ }^{3}$, M. Cutolo ${ }^{3}$, D. Elewaut ${ }^{4}$, R. Gerli ${ }^{2}$, I. Peene ${ }^{5}$, V. Smith ${ }^{4}$ on behalf of the EULAR Study Group on Microcirculation in Rheumatic Diseases. ${ }^{1}$ Ghent University; Ghent University Hospital, Ghent, Belgium; ${ }^{2}$ University of Perugia, Perugia, Italy; ${ }^{3}$ Research Laboratory and Academic Division of Clinical Rheumatology, Genoa, Italy; ${ }^{4}$ Ghent University; Ghent University Hospital; Unit for Molecular Immunology and Inflammation, 
Inflammation Research Center (IRC), VIB, Ghent, Belgium; ${ }^{5}$ Ghent University Hospital, Ghent, Belgium

Background: Sjögren Syndrome (SS) is a rheumatic connective tissue disease in which vascular involvement (e.g. Raynaud's phenomenon) may occur. No systematic review exists elucidating on the role of nailfold capillaroscopy in SS.

Objectives: To give a standardised overview of capillaroscopic changes and clinical associations in SS.

Methods: The literature was searched through in three databases by two reviewers. All published original studies which assess patients with SS by capillaroscopy were revised. A quality assessment was applied, based on sample size, population description, presence of a control group, presence of instrumental specifications and/or standardly applied capillaroscopic methodology, presence of clear descriptions of capillaroscopic parameters and based on the used statistical analysis. The capillaroscopic findings were described in a EULAR consented standardised way (1). Significant associations of capillaroscopic parameters in SS-patients with clinical and laboratory variables were also reported.

Results: The literature search resulted in 826 hits. Based on title and abstract screening 519 original studies were retained and of these, 12 full texts described an assessment by nailfold capillaroscopy in SS. Six studies (four case-control studies and two case-series) were retained after performing a critical quality assessment (fig 1). EULAR standardised description (table 1) attested conclusive results for capillary 'morphology', suggesting a not higher prevalence of abnormal shapes in SS than in healthy $(2,3)$. Concerning clinical associations, capillary density was associated with Raynaud in two studies and with interstitial lung disease in one study (2-4). No association between serologic features (anti-nuclear antibodies, anti-SSA, anti-SSB and anti-RF) and capillaroscopic parameters were found $(2,5)$

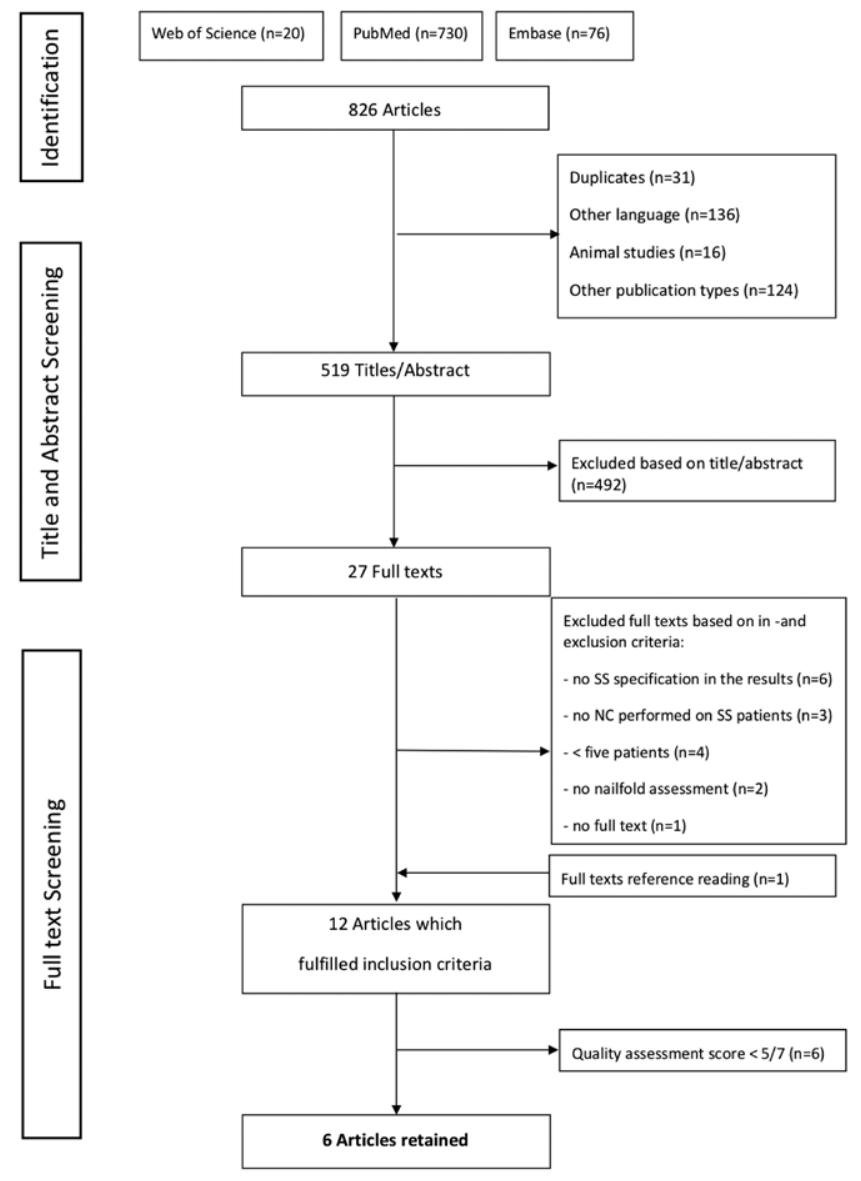

Fig 1. Flowchart of the search strategy about nailfold capillaroscopy in Sjögren Syndrome

Conclusion: A small number of studies have investigated the role of nailfold capillaroscopy in SS. Prospective follow up studies with standard evaluation and capillaroscopy in SS are warranted.

References:

[1] Smith et al Autoimmun Rev 2020, DOI: 10.1016/j.autrev.2020.102458

[2] Capobianco et al Clin Exp Rheumatol 2005;23(6):789-94

[3] Tektonidou et al Rheumatology (Oxford, England) 1999;38(9):826-30

[4] Cakmakci et al Tuberk Torakx 2015;63:22-30

[5] Corominas et al Rheumatol Int 2016;36(3):365-9
Table 1. Standardised description of capillaroscopic characteristics in Sjögren's Syndrome vs Healthy Legend. Only studies mentioning p-values

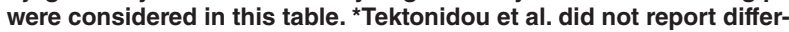
ences between healthy controls and the SS group as a whole, but rather reported differences between healthy controls and subgroups of patients with/without Raynaud's and with/without centromere antibodies.

\begin{tabular}{|c|c|c|c|c|}
\hline Assessment & Parameter & Significant & $\begin{array}{c}\text { Not } \\
\text { significant }\end{array}$ & Conclusion \\
\hline \multirow[t]{6}{*}{ Quantitative } & Density & $\begin{array}{l}1 \text { study [2] } \\
0 \text { studies }\end{array}$ & $\begin{array}{l}1 \text { study [3] } \\
0 \text { studies }\end{array}$ & $\begin{array}{l}\text { Not conclusive } \\
\text { Not conclusive }\end{array}$ \\
\hline & $\begin{array}{l}\text { Dilation } \\
\text { Giant }\end{array}$ & O studies & $\begin{array}{l}1 \text { studies } \\
1 \text { study [2] }\end{array}$ & Not conclusive \\
\hline & $\begin{array}{c}\text { Normal } \\
\text { morphology }\end{array}$ & $\begin{array}{l}0 \text { studies } \\
0 \text { studies }\end{array}$ & $\begin{array}{l}0 \text { studies } \\
1 \text { study [3] }\end{array}$ & Not conclusive \\
\hline & $\begin{array}{l}\text { Hairpin shaped } \\
\text { Tortuosity }\end{array}$ & 0 studies & 1 study [3] & \\
\hline & $\begin{array}{l}\text { Crossing } \\
\text { Abnormal } \\
\text { morphology }\end{array}$ & 0 studies & $\begin{array}{l}2 \text { studies } \\
{[2,3]}\end{array}$ & $\begin{array}{c}\text { Equal absence of abnormal } \\
\text { morphology in SS vs } \\
\text { healthy controls }\end{array}$ \\
\hline & Haemorrhages & 0 studies & $\begin{array}{c}2 \text { studies } \\
{[2,3]}\end{array}$ & Not conclusive $^{\star}$ \\
\hline $\begin{array}{l}\text { Semi } \\
\text { quantitative }\end{array}$ & & 0 studies & 0 studies & No data \\
\hline \multirow[t]{4}{*}{ Qualitative } & Normal & 0 studies & 1 study [3] & Not conclusive* $^{*}$ \\
\hline & Non specific & 0 studies & 1 study [3] & Not conclusive ${ }^{\star}$ \\
\hline & abnormalities & 0 studies & 0 studies & No data \\
\hline & $\begin{array}{l}\text { Scleroderma } \\
\text { pattern }\end{array}$ & & & \\
\hline
\end{tabular}

Disclosure of Interests: Karin Melsens: None declared, Maria C. Leone: None declared, Sabrina Paolino: None declared, Maurizio Cutolo Grant/research suppor from: Bristol-Myers Squibb, Actelion, Celgene, Consultant of: Bristol-Myers Squibb Speakers bureau: Sigma-Alpha, Dirk Elewaut: None declared, Roberto Gerli: None declared, Isabelle Peene: None declared, Vanessa Smith Grant/research support from: The affiliated company received grants from Research Foundation - Flanders (FWO), Belgian Fund for Scientific Research in Rheumatic diseases (FWRO) Boehringer Ingelheim Pharma GmbH \& Co and Janssen-Cilag NV, Consultant of: Boehringer-Ingelheim Pharma GmbH \& Co, Speakers bureau: Actelion Pharmaceuticals Ltd, Boehringer-Ingelheim Pharma GmbH \& Co and UCB Biopharma Sprl DOI: 10.1136/annrheumdis-2020-eular.1687

\section{\begin{tabular}{|l|l}
\hline THU0279 & PREVALENCE AND RISK FACTORS OF HERPES
\end{tabular} ZOSTER REACTIVATION IN PATIENTS WITH BIOPSY PROVEN LUPUS NEPHRITIS UNDERGOING IMMUNOSUPPRESSIVE THERAPIES}

C. C. Mok ${ }^{1}$, S. M. Tse ${ }^{1}$, K. L. Chan ${ }^{1}$, L. Y. Ho ${ }^{1}$ on behalf of NA. ${ }^{1}$ Tuen Mun Hospital, Medicine, Hong Kong, Hong Kong (SAR)

Background: Herpes zoster $(\mathrm{HZ})$ reactivation is fairly common in patients with systemic lupus erythematosus (SLE). However, there is a paucity of studies that reported the risk factors of $\mathrm{HZ}$ reactivation in well-defined subsets of SLE patients. Objectives: To study the prevalence of $\mathrm{HZ}$ reactivation in patients with active biopsy confirmed lupus nephritis (LN) undergoing immunosuppressive therapies. Methods: Patients who had biopsy proven active LN that was treated with immunosuppressive regimens in our unit between 2003 and 2018 were retrospectively reviewed for the occurrence of $\mathrm{HZ}$ reactivation within 2 years' therapies. $\mathrm{HZ}$ was a clinical diagnosis based on history and physical signs by attending physicians. The following were collected: age and SLE duration at renal biopsy, sex, SLE disease activity scores, maximum daily dose and total duration of high-dose prednisolone and other immunosuppressive drugs in the induction period, maintenance therapies laboratory parameters at renal biopsy and 6 months post-therapy that included lupus serology, albumin, globulin, immunoglobulin levels (lgG/A/M) and white cell counts (lymphocyte and neutrophil), histological classes of LN and clinical response at 6 month and 2 years. The incidence of $\mathrm{HZ}$ reactivation within 2 years of active $\mathrm{LN}$ treatment and the total prevalence of $\mathrm{HZ}$ infection over time until last follow-up was calculated. Risk factors for $\mathrm{HZ}$ reactivation were studied by logistic regression. Results: 251 patients with 311 episodes of active LN were studied ( $92 \%$ women; age $34.2 \pm 14.2$ years at first renal biopsy). The distribution of histological classes (WHO or ISN/RPS) was: class III/IV $\pm \mathrm{V}$ (69\%), I/II/V/VI (31\%). First-time renal disease occurred in $61 \%$ of patients. Induction treatment regimens were: prednisolone in combination with CYC (17\%), azathioprine (11\%), MMF (42\%), tacrolimus (25\%). Within 2 years of immunosuppressive therapies, 55 (18\%) episodes of LN were complicated by $\mathrm{HZ}$ infection. The incidence of $\mathrm{HZ}$ reactivation was $8.84 / 100$ patient-year. The median time for $\mathrm{HZ}$ reactivation since $\mathrm{LN}$ treatment was 11 months. 28 patients had $\mathrm{HZ}$ infection occurring longer than 2 years post-therapy, giving an overall prevalence of 3.24/100 patient-years. The distribution of $\mathrm{HZ}$ lesions was: head and neck region (15\%), lower limbs (27\%), trunk (55\%) and upper limbs (4\%). Fourteen episodes of HZ (25\%) were treated by intravenous anti-viral drugs while others were treated at out-patient settings 